\title{
5 ONG'S E AS POLÍTICAS PÚBLICAS NA CONSTRUÇÃo do ESTAdO DEMOCRÁtICO
}

\section{Sílvio Caccia Bava}

$\Delta$ ONG's existem no Brasil
há muito tempo. Novo é o nome - Organizaçōes nãogovernamentais - que lhes deram o Banco Mundial e o sistema das Naçōes Unidas. Antes eram conhecidas como centros de pesquisa, associações promotoras de educação popular, entidades de assessoria a movimentos sociais etc.

Nos últimos 20 anos foi se construindo uma história da relação das ONG's com os setores populares e suas entidades, sejam elas associaçōes de bairro, sindicatos, movimentos ambientalistas, de mulheres, de negros, indígenas, $e$ outros.

Essa relação sempre foi essencialmente politica: buscava-se fortalecer os múltiplos atores sociais coletivos que, na sua relaçāo com o Estado, expressavam demandas pelo reconhecimento de direitos, por medidas concretas que atendessem suas necessidades de saúde, cducação, moradia, elc.

Na linguagem atual da ciência política as ONG's têm como seu principal motivo de existência o este novo cenário polttico
dos anos 90 , as Organiza-
çóes Não-Governamentais aparecem como setores com voz própria, articuladas borizontalmente com as demais instituiçōes que lutam por uma soctedade democrática. No futuro governo, as ONGs serão chamadas a participar da implementação de politicas sociais. Se desenba, assim, uma nova realidade, que exigirá de todos um um grande esforço na construção de parcerias que se fazem necessárias para enfrentar a crise social brasileira.

empowerment dos setores sociais excluídos ou discriminados, de toda forma, privados de seus direitos. Fortalecer atores sociais emergentes significava auxiliar na sua organizaçāo, sistematizar suas reivindicaçōes, estabelecer os contatos que permitissem aos movimentos conquistar o apoio de outros setores da sociedade e o espaço público para suas demandas. Um trabalho que se fazia numa linha de enfrentamento com o Estado autoritário, que gerou uma cultura entre as ONG's e os movimentos sociais, uma compreensāo do Estado como um adversário a ser desafiado. 


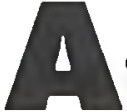

democratização da sociedade brasileira gerou novas relaçōes entre os atores coletivos presentes na socicdade civil e destes com o Estado, especialmente na relação de governos municipais com a cidadania. Ai foi onde mais se avançou na criaçāo de um novo modo de governar. Mas também a nível federal foram se criando novas relaçōes. Apesar de tơla a resistência à participação popular por parte do Estado - o que também é uma herança histórica do periodo autoritário.

Articulações como o Fórum Nacional da Reforma Urbana, como o Fórum Brasileiro de Movimentos Sociais e ONG's em Defesa do Meio Ambiente e do Desenvolvimento, são expressões de um conjun to de entidades muito diferentes entre si, mas que se somam ao construirem, juntas, propostas de intervenção.

Na luta pela Reforma Urbana, por exemplo, estão jun tas centrais sindicais, sindicatos, associações profissionais, confederaçōes e federaçōes de sociedades a migos do bairro, movimentos populares e ONG's. Este Forru tem atuado intensamente desde o periodo constituinte e, entre outras coisas, garantiu a inclusāo de um capítulo sobre política urbana na nossa nova Constituição.

Neste novo cenário político dos anos 90 as ONG's aparecem como atores com voz própria, articula- das horizontalmente com as demais instituições que lutam por uma sociedade democrática. Suas práticas, como diz Betinho, se fundam em valores como liberdade, igualdade, diversidade, participação, solidariedade. Ao contrário do que se veicula em jomais que recentemente abriram uma clara campanha contra as ONG's, clas nāo são teleguiadas por agências de cooperação intemacionais ou governos estrangeiros. Um de seus traços caracteristicos é a autonomia. São independentes do Estado, dos partidos políticos, das igrejas c também da cooperação internacional. São relações construídas por anos de parceria, o que tam. bém inclui conflitos que, em alguns casos, se expressam cm rupturas das relaçōes.

O perfil político das ONG's brasileiras é fruto de mais de 20 anos de trabalhos, que foram legitimando essas ONG's junto aos demais atores da sociedade. ONG's não é sindicato, não representa ninguém. Se afirma pelo trabalho que faz, ou desaparece.

Em outros países da América Latina as ONG's têm o perfil histórico de suas práticas. Do espaço que soubcram ou não conquistar seja na relação com o Estado, seja com a sociedade civil. E há exemplos de ONG's que perderam sua autonomia, se submeteram a projetos que, por exemplo, as transformaram em braços executivos de politicas do Estado. Isso aconteceu e acontece ainda hoje com maior 
expressão nos países que se submeteram às condicionalidades do Fundo Monetário Intemacional e onde seus govemos aplicaram o receituário de medidas econômicas que configuram o que se convencionou chamar de ajustes estruturais. Juntamente com os ajustes estruturais vêm as políticas compensatórias, e para implementar essas politicas compensatórias os governos têm chamado as ONG's a participar.

No futuro governo Fernando Hen rique as ONG's serão chamadas a participar da implementação de políticas sociais. Esta é u ma oferta do governo e uma reivindicação das ONG's. Trata-se de uma iniciativa inovadora por parte do Estado, que demonstra com isso uma vontade política de reforma do Estado e de uma democratização do espaço público.

Se desenha assim uma nova realidade, que exigirá de todos um grande esforço na construção das parcerias que se fazem necessárias para enfrentar a crise social brasileira.

Da parte das ONG's se colocam muitos desafios, entre eles aumentar sua capacidade propositiva, estreitar laços com os demais atores coletivos da sociedade civil, colaborar na construção de espaços públicos de formulação, implementação e controle social sobre as políticas públicas.
Da parte do Estado os desafios são igualmente importantes. Entre eles estāo o da transparência, isto é, a exposição pública das informaçôes e do processo decisório sobre as políticas sociais; o do reconhecimento da alteridade, isto é, de que as $O N G$ 's não são c não querem ser um mero braço executivo de políticas definidas nas instâncias govemamentais e sim atores que querem preservar sua autonomia e participar do processo decisório sobre as políticas nas quais se en rolvam.

As relaçōes ONG's/Estado sempre foram delicadas. Para que elas se consolidem em parcerias e superem os limites construídos por uma cultura autoritária é preciso que o Estado assuma um paradoxo: se preocupe em respeitar a autonomia das ONG's e, ao mesmo tempo, se preocupe também com fortalecimento institucional das ONG's. Afinal, um Estado democrático depende de uma sociedade civil forte, organizada, propositiva.

O estágio e a qualidade da democracia que uma determinada sociedade conquista pode ser medido de muitas formas. Na Suécia, por exemplo, as ONG's são financiadas $100 \%$ pelo Estado c, mesmo nesta condição, têm asseguradas por leis $\mathrm{c}$ fundos públicos sua autonomia, sua independência, sua postura crítica frente às ações do governo. E para que possam exercer este papel de verdadeiros ombudsmans das açōes do gover- 
no, têm assegurado espaço na TV para exercer esse papel crítico perante todos os cidadãos suecos.

No Brasil, as ONG's se somam às demais entidades e movimentos que lutam pela democratização do pais, que lutam por condiçōes dignas de vida para todo cidadão brasileiro. Desta perspectiva estarão cumprindo apenas o seu dever ao aceitarem discutir os termos da parceria ONG's/Estado, uma relação delicada que se fundará em compromissos sempre provisórios.

\section{Resumen}

\section{LAS ONGS Y LAS POLITICAS PÚ- BLICAS EN LA CONSTRUCCIÓN DEL ESTADO DEMOCRÁTICO}

Fin este nuevo escenario político de los años 90, las Organizaciones No Gubernamentales aparecen como sectores con voz propia, articuladas horizontalmente con las demás instituciones que luchan por una sociedad democrática. En el futuro gobiemo, las ONGs serán llamadas a participar de la implementación de políticas sociales. Se delinea, así, una nueva realidad, que exigirá de todos un gran esfuerzo en la construcción de grupos que se hacen necesarios para enfrentar la crisis social brasileña.

\section{Abstract}

NGOs AND PUBLIC POLICIES IN CONSTRUCTION OF A DEMOCRATIC STATE

In the new political scenario of the 1990s, the Non-Governmental Organizations (NGOs) appear as sectors with their own voice, tied in a horizontal relation with other institutions which fight a democratic society. In the next Administration, the NGOs will be called on to participate in implementation of social policies. Thus, a new reality is being designed that will demand a great effort from everyone to construct partnerships needed to confront the Brazilian social crisis.

Sílvio Caccia Bava é sociólogo, presidente da Associação Brasileira de ONG's - ABONG. 